Situs Jurnal : http://ejournal.stiepancasetia.ac.id/index.php/jieb

Jilid 6 Nomor 3 November 2020

Hal 453-468

\title{
ANALISIS SISTEM PENGENDALIAN INTERN TERHADAP PIUTANG PADA PT.DIVAINDO SENTRAL SARANA BANJARBARU
}

\author{
Maria Anastasia*, Ferry Setiawan
}

Abstrak : Penelitian ini bertujuan untuk mengetahui dan menganalis Untuk mengetahui sistem pengendalian intern terhadap piutang pada PT.Divaindo Sentral Sarana selama ini dan juga Untuk memberi masukan sistem pengendalian intern terhadap piutang pada PT.Divaindo Sentral Sarana yang seharusnya dilakuan.

Dalam penelitian ini Metode pendekatan penelitian yang penulis gunakan dalam penelitian ini adalah metode kualitatif, sedangkan Populasi dalam penelitian ini adalah seluruh karyawan PT.Divaindo Sentral Sarana yang berjumlah 48 orang dan diambil sampel yang penulis tentukan berjumlah 15 orang dengan menggunakan purposive sampling Menurut Sugiyono (2017:85). jenis dan sumber data yang digunakan adalah data kauantitatif dan data kualitatif serta sumber data primer dan data skunder disamping itu Teknik pengumpulan data terdiri dari obsevasi, wawancara dan dokumentasi. Pada penelitian ini menggunakan Teknik analisis data kualitatif yang mana dalam bentuk keterangan dan pembahasan teoritis yang bertujuan menganalisa hal-hal yang dapat dianalisa bukan dengan angka-angka tetapi dengan teori-teori yang dibuktikan dengan kenyataan yang terjadi.

Hasil penelitian menunjukan pengendalian intern piutang harus memperhatikan beberapa hal, yaitu mengenai komponen dan unsur- unsur pengendalian yang teridiri dari 1 . lingkungan pengendalian dengan melihat nilai - nilai etika, kebijakan dan praktek pegawai 2. Penentuan resiko dg menggunakan analisa 5C dimana hal ini sudah cukup baik, tetapi dalam penentuan target collection sebaiknya ditingkatkan lagi dari 93,5\% menjadi 98\%. 3. Aktivitas pengendalian harus lebih memperhatikan control dan pengawasa. 4. Informasi dan komunikasi harus disediakan informasi pembayaran nasabah melalui online dan 5. Pengawsan dan pemantauan lebih memperhatikan SOP yang dijalankan agar tidak dilanggar serta memperhatikan unsur- unsur nya.

Kata Kunci : Sistem Pengendalian Intern, Piutang Usaha 


\section{PENDAHULUAN}

Perusahaan adalah tempat terjadinya kegiatan produksi yang mengelola sumbersumber ekonomi untuk menyediakan barang dan jasa bagi masyarakat dengan tujuan untuk memperoleh keuntungan dan agar dapat memuaskan kebutuhan masyarakat. Piutang usaha pada suatu perusahaan adalah salah satu bagian terbesar dari aktiva lancar, serta bagian terbesar dari total aktiva perusahaan. Oleh karena itu pengendalian internal terhadap piutang usaha ini sangat penting diterapkan. Kecurangan dalam siklus kerja sangat sering terjadi sehingga dapat merugikan perusahaan. Kecurangan yang sering terjadi pada bagian piutang usaha adalah tidak mencatat pembayaran dari debitur dan mengantongi uangnya, menunda pencatatan piutang dengan melakukan cash lapping, melakukan pembukuan palsu atas mutasi piutang, dan lain sebagainya. Pengendalian internal perusahaan merupakan salah satu cara yang digunakan untuk meningkatkan efektivitas dan efisiensi, menjaga aset, memberikan informasi yang akurat, mendorong dipatuhinya kebijakan manajemen yang sudah ditetapkan. Pengendalian internal dapat mencegah kerugian atas pengolahan sumber daya perusahaan. Pengendalian internal dapat menyediakan informasi tentang bagaimana menilai kinerja perusahaan dan manajemen perusahaan serta menyediakan informasi yang akan digunakan sebagai pedoman dalam perencanaan

PT.Divaindo Sentral Sarana merupakan salah satu perusahaan dagang yang bergerak dalam penjualan barang elektronik maupun furnitur baik secara tunai maupun kredit, namun aktivitas penjualannya didominasi oleh penjualan secara kredit. Pada perusahaan ini pengelolaan piutang sangatlah penting, karena sebagian besar operasional perusahaan ini berasal dari pengelolaan uang piutang tersebut.

Penjualan secara kredit ini banyak menimbulkan risiko, yaitu terciptanya piutang yang tidak tertagih. Hal ini terjadi karena faktor internal yaitu kelalaian dan kecurangan dari pihak karyawan perusahaan sendiri, dan dari faktor eksternal yang terjadi karena konsumen tersebut tidak membayar sehingga terjadi tunggakan. Berikut data piutang yang dimiliki PT.Divaindo Sentral Sarana dalam kurun waktu 5 tahun terakhir.

\begin{tabular}{|l|l|l|l|l|}
\hline $\begin{array}{l}\text { N } \\
\text { O }\end{array}$ & $\begin{array}{l}\text { TAH } \\
\text { UN }\end{array}$ & $\begin{array}{l}\text { JUMLAH } \\
\text { PIUTANG }\end{array}$ & $\begin{array}{l}\text { TUNGG } \\
\text { AKAN }\end{array}$ & $\%$ \\
\hline 1 & 2014 & $\begin{array}{l}10.229 .772 .00 \\
0\end{array}$ & $\begin{array}{l}484.775 .0 \\
00\end{array}$ & $\begin{array}{l}4,7 \\
4 \%\end{array}$ \\
\hline 2 & 2015 & 7.805 .737 .000 & $\begin{array}{l}366.132 .0 \\
00\end{array}$ & $\begin{array}{l}4,6 \\
9 \%\end{array}$ \\
\hline 3 & 2016 & 7.884 .617 .000 & $\begin{array}{l}368.791 .0 \\
00\end{array}$ & $\begin{array}{l}4,6 \\
8 \%\end{array}$ \\
\hline 4 & 2017 & 9.328 .584 .000 & $\begin{array}{l}421.860 .0 \\
00\end{array}$ & $\begin{array}{l}4,5 \\
2 \%\end{array}$ \\
\hline 5 & 2018 & 8.299 .093 .000 & $\begin{array}{l}480.310 .0 \\
00\end{array}$ & $\begin{array}{l}5,7 \\
9 \%\end{array}$ \\
\hline
\end{tabular}

\section{Daftar Nilai Piutang PT.Divaindo Sentral Sarana Tahun 2014 - 2018}

Sumber Data : PT.Divaindo Sentral Sarana, 2019

Berdasarkan Tabel 1.1 di atas, dapat kita lihat perkembangan piutang dan besarnya tunggakan pada PT.Divaindo Sentral Sarana, dimana pada tahun 2014 memiliki piutang sebesar Rp.10.229.772.000,- dan tunggakan Rp.484.775.000,- (4,74\%), pada tahun 2015 memiliki piutang sebesar Rp.7.805.737.000,- dan tunggakan Rp.366.132.000,- (4,69\%), pada tahun 2016 memiliki piutang sebesar Rp.7.884.617.000,- dan tunggakan Rp.368.791.000,- (4,68\%), pada tahun 2017 memiliki piutang sebesar Rp.9.328.584.000,- dan tunggakan Rp.421.860.000,- (4,52\%) terjadi kenaikan jumlah piutang pada tahun 2017 dibandingkan tahun-tahun sebelumnya begitu juga terjadi kenaikan nilai tunggakannya tetapi secara presentasi lebih rendah karena pembaginya yang besar, pada tahun 2018 memiliki piutang sebesar Rp.8.299.093.000,- dan tunggakan Rp.480.310.000,- (5,79\%).

Peningkatan tunggakan, terutama pada piutang tahun 2018 terjadi karena banyaknya konsumen yang tidak membayar karena analisa pelepasan kredit yang kurang 
tepat dan juga beberapa penggelapan yang dilakukan oleh petugas penagih yaitu dengan tidak disetornya pembayaran konsumen yang mengakibatkan tunggakan meningkat, hal ini salah satunya disebabkan oleh otorisasi yang tidak jelas, dimana ada beberapa karyawan yang tidak berwenang untuk menagih seperti supervisor marketing yang seharusnya bertindak sebagai tenaga penjual tetapi dilibatkan dalam proses penagihan. Hal ini jelas sangat bertentangan dengan unsur-unsur SPI (Sistem Pengendalian Intern) yaitu tidak adanya pemisahan tanggung jawab fungsional secara tegas, dan penilaian karyawan yang mutunya tidak sesuai dengan tanggung jawabnya.

Untuk itu perlu ditingkatkan lagi pengawasan dalam menjalankan SOP (Standard Operating Procedure) sehingga penyelewengan oleh tenaga penagih dan juga perangkat yang berkaitan dalam penanganan piutang tidak terjadi lagi.

Berdasarkan masalah tersebut, penulis tertarik untuk melakukan penelitian dengan judul "Analisis Sistem Pengendalian Intern Terhadap Piutang Pada PT.Divaindo Sentral Sarana".

Berdasarkan masalah di atas, maka masalah dalam penelitian ini dapat diidentifikasi sebagai berikut :

1. Bagaimanakah sistem pengendalian intern terhadap piutang pada PT.Divaindo Sentral Sarana yang selama ini dijalankan?

2. Bagaimanakah sistem pengendalian intern terhadap piutang pada PT.Divaindo Sentral Sarana yang seharusnya?

Tujuan utama yang ingin dicapai dalam penelitian ini adalah sebagai berikut :

1. Untuk mengetahui sistem pengendalian intern terhadap piutang pada PT.Divaindo Sentral Sarana selama ini.

2. Untuk memberi masukan sistem pengendalian intern terhadap piutang pada PT.Divaindo Sentral Sarana yang seharusnya.

TINJAUAN PUSTAKA

Pengertian Sistem
Menurut Romney dan Steinbart (2015:3), sistem adalah suatu rangkaian yang terdiri dari dua atau lebih komponen yang saling berhubungan dan saling berinteraksi satu sama lain untuk mencapai tujuan dimana sistem biasanya terbagi dalam sub sistem yang lebih kecil yang mendukung sistem yang lebih besar.

\section{Komponen Sistem}

Komponen sistem menurut Romney (2015) terdiri dari lima komponen diantaranya:

1) Orang-orang, yang mengoperasikan sistem tersebut dan melaksanakan berbagai fungsi.

2) Prosedur-prosedur, baik manual maupun yang terotomatisasi yang dilibatkan dalam mengumpulkan, memproses, menyimpan data tentang aktivitasaktivitas organisasi.

3) Data tentang proses-proses bisnis organisasi.

4) Perangkat Lunak/Software yang dipakai untuk memproses data.

5) Infrastruktur teknologi informasi termasuk komputer, peralatan pendukung, dan peralatan untuk komunikasi jaringan.

\section{Pengertian Pengendalian}

Pengertian pengendalian menurut Kamus Besar Bahasa Indonesia adalah "pengawasan atas kemajuan (tugas) dengan membandingkan antara hasil dan sasaran secara teratur serta menyesuaikan usaha (kegiatan) dalam hasil pengawasan.

\section{Pengertian Pengendalian Internal}

Menurut Romney dan Steinbart (2015:226), pengendalian internal adalah sebuah proses yang menyebar keseluruh aktivitas pengoperasian perusahaan dan merupakan bagian integral dari aktivitas manajemen dimana pengendalian internal memberikan jaminan yang memadai untuk tujuan pengendalian berupa mengamankan aset, mengelola catatan secara detail yang baik untuk melaporkan aset perusahaan secara akurat dan wajar, memberikan informasi yang akurat dan reliabel, menyiapkan laporan keuangan yang sesuai dengan kriteria yang ditetapkan dan mendorong dan memperbaiki efisiensi operasional.

Tujuan Sistem Pengendalian Internal 
Menurut Mulyadi (2014:163) mengatakan tujuan sistem pengendalian internal yang efektif diantaranya :

1) Menjaga keamanan harta perusahaan dan juga catatan organisasi.

2) Memeriksa ketelitian atas kecermatan dan kebenaran data akuntansi.

3) Memajukan efisiensi perusahaan.

4) Membantu agar tidak ada penyimpangan dari kebijakan-kebijakan manjemen yang ada.

\section{Komponen Pengendalian Intern}

Menurut Committe Of Sponsoring Organizations (COSO) (2013: 56), pengendalian internal memiliki lima komponen yaitu :

1) Lingkungan Pengendalian

a. Struktur organisasi

b. Komitmen terhadap integritas dan nilai-nilai etika

c. Komitmen terhadap kompetensi

d. Peraturan dan kode etik karyawan

e. Metode penetapan tanggung jawab dan wewenang

f. Kebijakan dan praktik untuk mengelola sumber daya manusia

2) Penilaian Risiko

a. Personil baru yang memiliki pemahaman berbeda atau tidak memadahi atas pengendalian internal.

b. Sistem informasi dan teknologi yang baru atau yang diperbarui mempengaruhi pemrosesan transaksi.

c. Produk dan aktifitas baru yang tidak dimengerti oleh karyawan akan menimbulkan risiko terganggunya proses bisnis perusahaan.

d. Bencana alam atau kerusakan politik seperti kebakaran, banjir, gempa bumi, perang, atau kerusuhan massa.

3) Kegiatan Pengendalian

a. Desain dokumen yang baik dan bernomor urut tercetak.

b. Pemisahan tugas. c. Otorisasi yang memadai atas transaksi bisnis.

d. Mengamankan harta dan catatan perusahaan.

4) Informasi dan Komunikasi

a. Mengisi dan mencatat semua transaksi yang valid.

b. Mengklarifikasi transaksi sebagaimana harusnya.

c. Mencatat transaksi pada periode yang tepat.

5) Kegiatan Pemantauan

a. Supervisi yang efektif

b. Pengauditan internal

Unsur - unsur pengendalian internal terdiri dari

a. Struktur organisasi yang memisahkan tanggung jawab fungsional secara tegas.

Pembagian tanggung jawab fungsional dalam organisasi ini didasarkan pada prinsip-prinsip berikut ini:

1) Harus dipisahkan fungsi-fungsi operasi dan penyimpanan dari fungsi akuntansi.

2) Suatu fungsi tidak boleh diberi tanggung jawab penuh untuk melaksanakan semua tahap suatu transaksi.

b. Sistem wewenang dan prosedur pencatatan yang memberikan perlindungan yang cukup terhadap kekayaan, utang, pendapatan dan biaya.

Dalam organisasi, setiap transaksi hanya terjadi atas dasar otorisasi dari pejabat yang memiliki wewenang untuk menyetujui terjadinya transaksi tersebut. Oleh karena itu, dalam organisasi harus dibuat sistem yang mengatur pembagian wewenang untuk otorisasi atas terlaksananya setiap transaksi. Sistem otorisasi akan menjamin dihasilkannya dokumen pembukuan yang dapat 
dipercaya, sehingga akan menjadi masukan yang dapat dipercaya bagi proses akuntansi.

c. Praktik yang sehat dalam melaksanakan tugas dan fungsi setiap unit organisasi.

Adapun cara-cara yang umumnya ditempuh oleh perusahaan dalam menciptakan praktik yang sehat adalah:

a) Penggunaan formulir bernomor urut tercetak yang pemakaiannya harus dipertanggungjawabkan oleh yang berwenang.

b) Pemeriksaan mendadak.

c) Setiap transaksi tidak boleh dilaksanakan dari awal sampai akhir oleh satu orang atau satu unit organisasi.

d) Perputaran jabatan.

e) Keharusan pengambilan cuti bagi karyawan yang berhak.

f) Secara periodik diadakan pencocokan fisik kekayaan dengan catatannya.

g) Pembentukan unit organisasi yang bertugas untuk mengecek efektivitas unsur-unsur sistem pengendalian internal yang lain.

d. Karyawan yang mutunya sesuai dengan tanggung jawabnya.

Bagaimanapun baiknya struktur organisasi, sistem otorisasi dan prosedur pencatatan, serta berbagai cara yang diciptakan untuk mendorong praktik yang sehat, semuanya tergantung kepada manusia yang melaksanakannya. Diantara 4 unsur pokok pengendalian internal tersebut diatas, unsur mutu karyawan merupakan unsur sistem pengendalian internal yang paling penting. Jika perusahaan memiliki karyawan yang kompeten dan jujur, unsur pengendalian yang lain dapat dikurangi sampai batas yang minimum dan perusahaan tetap mampu menghasilkan pertanggung jawaban keuangan yang dapat diandalkan karyawan yang jujur dan ahli dalam bidang yang menjadi tanggung jawabnya akan dapat melaksanakan pekerjaannya dengan efisien dan efektif, meskipun hanya sedikit unsur sistem pengendalian internal yang mendukungnya.

\section{Konsep Piutang}

\section{A. Pengertian Piutang}

Menurut Mardiasmo (2016:51), "Piutang adalah tagihan yang berasal dari penjualan barang dagangan dan jasa secara kredit". Sedangkan menurut Warren dkk (2014:448), "Piutang mencakup seluruh bagian uang yang diklaim terhadap entitas lain, termasuk perorangan, perusahaan, dan organisasi lain. Piutang-piutang ini biasanya merupakan bagian yang signifikan dari total aset lancar".

Menurut Pernyataan Standar Akuntansi Keuangan (PSAK) No.43 menyatakan bahwa "Piutang adalah jenis pembiayaan dalam bentuk pembelian dan atau pengalihan piutang atau tagihan jangka pendek suatu perusahaan yang berasal dari transaksi usaha" Menurut Ikatan Akuntansi Indonesia dalam Pernyataan Standar Akuntansi Keuangan (PSAK) No.9 piutang adalah "Piutang usaha meliputi piutang yang timbul karena penjualan produk atau penyerahan jasa dalam rangka kegiatan usaha normal perusahaan".

Dari pengertian para ahli yang telah dikemukakan maka dapat disimpulkan bahwa piutang adalah suatu tagihan (klaim) perusahaan kepada pihak lain, yaitu konsumen atau pelanggan baik perorangan maupun kelompok (badan usaha) yang ditimbulkan oleh penjualan barang atau jasa secara kredit dalam kegiatan operasional perusahaan.

\section{B. Klasifikasi Piutang}

Piutang pada normalnya kegiatan perusahaan akan dilunasi dalam jangka waktu kurang dari satu tahun sehingga 
dikelompokkan ke dalam aset lancar. Apabila pelunasan lebih dari satu tahun maka tidak dilaporkan dalam kelompok aset lancar akan tetapi termasuk ke dalam aset lain-lain.

Menurut Ikatan Akuntan Indonesia dalam SAK (2015:1.13) menyatakan bahwa, entitas mengklasifikasikan aset sebagai aset lancar jika :

1) Entitas memperkirakan akan merealisasikan aset, atau memiliki intensi untuk menjual atau menggunakannya, dalam siklus operasi normal

2) Entitas memiliki aset untuk tujuan diperdagangkan

3) Entitas memperkirakan akan merealisasi aset dalam jangka waktu dua belas bulan setelah periode pelaporan

4) Aset merupakan kas atau setara kas, kecuali aset tersebut dibatasi pertukaran atau penggunaannya untuk menyelesaikan liabilitas sekurangkurangnya dua belas bulan setelah periode pelaporan.

Standar akuntansi instrumen keuangan menyebutkan salah satu klasifikasi aset keuangan adalah pinjaman yang diberikan dan piutang. Kriterianya adalah aset keuangan nonderivatif yang pembayarannya telah ditentukan dan tidak memiliki kuotasi di pasar aktif.

Menurut Martani dkk (2014:196197) piutang dapat diklasifikasikan menjadi tiga yaitu:

1) Piutang Dagang

Piutang dagang merupakan klaim suatu perusahaan pada pihak lain baik yang terkait dengan transaksi penjualan/pendapatan.

2) Wesel Tagih

Wesel tagih merupakan klaim perusahaan kepada pihak ketiga yang didukung janji tertulis untuk membayar dalam jangka waktu tertentu.

3) Piutang Penghasilan

Penggunaan dasar waktu dalam akuntansi mengakibatan adanya pengakuan terhadap penghasilanpenghasilan yang masih akan diterima.
Penghasilan-penghasilan seperti itu semua atas dasar waktu, sehingga pada akhir periode dihitung berapa jumlah yang sudah menjadi pendapatan dan jumlah tersebut dicatat sebagai piutang penghasilan.

Berdasarkan penjelasan di atas, maka dapat dinyatakan bahwa piutang digolongkan menjadi tiga yaitu :

\section{1) Piutang Dagang}

Piutang dagang merupakan piutang yang timbul dari transaksi penjualan barang atau jasa secara kredit yang akan dilunasi dalam jangka waktu kurang dari satu tahun.

2) Piutang Bukan Dagang

Piutang ini merupakan piutang yang bukan timbul akibat penjualan barang atau jasa secara kredit melainkan dari penjualan saham dan penjualan dividen.

3) Piutang Lain-Lain

Piutang ini meliputi piutang bunga, piutang pajak, piutang penghasilan dan piutang karyawan.

\section{Pengelolaan Piutang}

Piutang meliputi segala macam tuntutan atau klaim kepada pihak ketiga sehingga diketahui bahwa akan ada penerimaan kas pada masa yang akan datang terkait dengan pelunasannya. Piutang diakui pada waktu hak milik beralih ke pembeli atau pada saat terjadinya transaksi yang dikenal dengan istilah accrual basis. Penggunaan accrual basis dalam akuntansi menimbulkan akibat adanya pengakuan terhadap penghasilanpenghasilan yang masih akan diterima. Menurut IAI dalam SAK (2015:9.4) menyatakan bahwa: jumlah bruto piutang harus disajikan dalam laporan posisi keuangan. Piutang dinyatakan sebesar jumlah bruto tagihan dikurangi dengan taksiran jumlah piutang yang tidak dapat ditagih. Jumlah bruto piutang harus tetap disajikan pada laporan posisi keuangan diikuti dengan penyisihan untuk piutang diragukan atau taksiran jumlah yang tidak dapat ditagih. 
Menurut Martani dkk (2014:201), pengakuan piutang dikaitkan dengan pengakuan pendapatan. Saat perusahaan telah mengakui pendapatannya maka perusahaan akan mengakui pendapatannya. Menurut IAI dalam SAK (2011:55), piutang diakui oleh entitas sebesar nilai wajar. Nilai wajar merupakan harga perolehan atau nilai pertukaran antara kedua belah pihak pada tanggal transaksi. Ayat jurnal untuk mengakui piutang atas penjualan barang atau jasa adalah :

\section{Piutang Dagang \\ XXX}

$$
\text { Penjualan }
$$

XXX

Kemudian pada saat piutang tersebut tertagih maka jurnalnya sebagai berikut

Kas

$\mathrm{XXX}$

$$
{ }_{\text {Pxx }} \text { Dagang }
$$

\section{Penagihan Kerugian Piutang}

Komponen aset lancar salah satunya adalah piutang. Penyajian piutang dalam laporan posisi keuangan menggunakan dasar pengukuran nilai realisasi/penyelesaian. Bahwa piutang dinyatakan sebesar jumlah piutang yang diharapkan akan ditagih dihitung dengan mengurangkan jumlah yang diperkirakan akan tidak dapat tertagih. Perhitungan ini merupakan aturan dari dasar pengukuran nilai realisasi dan menjadi hubungan antara kerugian piutang dengan penjualanpenjualan yang mengakibatkan timbulnya piutang tersebut. Hubungan ini dilandasi dengan asumsi bahwa kerugian piutang dibebankan pada periode yang bersangkutan.

Permasalahan yang timbul akibat kerugian piutang adalah bagaimana menetapkan seberapa besarnya jumlah yang harus disisihkan sebagai kerugian piutang. Hal ini memerlukan adanya penilaian piutang yang tak tertagih. Selain itu, penghapusan piutang juga diperlukan untuk menghapus piutang yang jelas-jelas tak tertagih. Penghapusan ini biasanya dilakukan karena debitur yang bersangkutan meninggal, melarikan diri, bangkrut atau sebab lainnya. Untuk menetapkan nilai dan penghapusan piutang yang tak tertagih tersebut, dilakukan analisis yang tepat sesuai dengan standar akuntansi yang berlaku secara umum.

Menurut Martani dkk (2014:217) yang disesuaikan dengan SAK (2011: 55), konsep penyisihan piutang dilakukan karena perusahaan dalam laporan keuangan harus menyajikan piutang sebesar jumlah yang dapat direalisasi. Untuk itu diperlukan estimasi jumlah yang tidak dapat ditagih di masa depan. Ada dua metode estimasi yang digunakan yaitu :

1) Metode Berdasarkan Penjualan

Metode ini menghitung jumlah beban piutang tak tertagih dari penjualan periode tertentu. Nilai penyisihan piutang akhir periode dihitung dari saldo awal penyisihan piutang ditambah penyisihan piutang periode berjalan, dikurangi penghapusan piutang dan ditambah jika ada piutang yang recovery.

2) Metode Berdasarkan Nilai Piutang Metode ini menggunakan pendekatan neraca karena perhitungan menggunakan nilai piutang dan jumlah yang dihitung adalah nilai penyisihan piutang pada akhir periode. Metode ini menghitung berapa jumlah penyisihan piutang dari saldo piutang akhir periode, beban penyisihan akan ditambahkan atau dikurangkan untuk mendapatkan saldo penyisihan piutang yang diinginkan.

Menurut Mardiasmo (2016:54-57) ada tiga metode penaksiran besarnya cadangan kerugian piutang yaitu:

1) Cadangan Kerugian Piutang atas Persentase dari Hasil Penjualan Bersih Dalam metode ini persentase kerugian piutang ditentukan dengan mengalikan sejumlah persentase tertentu dengan hasil penjualan bersih.

2) Cadangan Kerugian Piutang atas Persentase dari Saldo Piutang

Perhitungan kerugian piutang dengan menaksir besarnya kerugian piutang berdasarkan persentase tertentu dari saldo piutang dagang pada akhir tahun yang bersangkutan.

3) Cadangan Kerugian Piutang atas Analisis Umur Piutang 
Kerugian piutang dapat ditaksir dengan cara menganalisis umur dari saldo piutang debitur-debitur perusahaan. Umur piutang masing-masing debitur digolong-golongkan, baik yang belum jatuh tempo maupun yang telah jatuh tempo.

\section{E. Penghapusan Piutang}

Ikatan Akuntan Indonesia dalam SAK (2011:55) secara spesifik menyebutkan, entitas menghentikan pengakuan aset keuangan, jika dan hanya jika :

1) Hak kontraktual atas arus kas yang berasal dari aset keuangan tersebut berakhir

2) Entitas mentransfer aset keuangan yang memenuhi kriteria penghentian pengakuan. Transfer aset keuangan adalah transfer hak kontraktual penerimaan kas dari aset keuangan atau tetap memiliki hak kontraktual untuk menerima tetapi memiliki kewajiban untuk membayar arus kas yang diterima tersebut kepada pihak lain. Dalam transfer aset keuangan, penghentian pengakuan akan dilakukan jika telah terjadi transfer manfaat dan risiko kepada pihak lain.

Aset keuangan yang sering dihentikan pengakuannya adalah salah satunya piutang usaha atau dagang. Piutang usaha atau dagang kurang terjamin pelunasannya dikarenakan tidak adanya suatu perjanjian khusus yang dibuat untuk memiliki kekuatan hukum. Maka piutang ada kemungkinan tidak akan tertagih. Piutang yang jelas-jelas tak dapat ditagih lagi harus dihapuskan dari rekening piutang. Penghapusan piutang ini merupakan suatu kerugian bagi perusahaan.

Ada dua metode yang digunakan untuk menangani piutang yang tak tertagih yaitu metode penghapusan langsung dan metode cadangan. Penghapusan langsung digunakan untuk piutang tak tertagih yang bersifat tidak sering atau frekuensinya rendah. Sedangkan metode cadangan digunakan untuk perusahaan yang sering terjadi kerugian piutang atas piutang tak tertagih.
Menurut Mardiasmo (2016:52-53) perlakuan akuntansi terhadap penghapusan piutang terdapat dua metode yaitu :

1) Metode Penghapusan Langsung

Menurut metode penghapusan langsung, apabila jelas-jelas diketahui adanya piutang yang tidak dapat ditagih, maka piutang tersebut dihapuskan dan dibebankan pada rekening kerugian piutang. Jurnal untuk mencatat penghapusan piutang tak tertagih adalah sebagai berikut :

Kerugian Piutang $\mathrm{XXX}$

\section{Piutang}

XXX

2) Metode Cadangan

Metode cadangan menuntut perusahaan menghitung jumlah kemungkinan piutang tak tertagih pada setiap akhir periode. Jurnal untuk mencatat kerugian piutang tak tertagih dengan metode cadangan adalah sebagai berikut :

Kerugian Piutang

$$
\text { Cadangan }
$$

\section{Kerugian Piutang} xxx

Jika dipastikan bahwa piutang tersebut tidak akan tertagih, maka jurnal tersebut harus dikeluarkan dari catatan perkiraan piutang usaha, dengan cara mengkreditkannya sebesar jumlah tersebut yaitu dengan jurnal sebagai berikut :

\section{Piutang}

Cadangan Kerugian XXX

Usaha

Piutang $\mathrm{xxx}$

Apabila piutang yang telah dihapuskan sebagai piutang tidak tertagih ini dalam periode berjalan, secara tidak diduga dapat diterima kembali pelunasannya, maka ayat jurnal yang diperlukan yaitu

Jurnal pembalik penghapusan piutang tak tertagih 
Piutang Usaha

$\mathrm{XxX}$

Cadangan

Kerugian Piutang

Jurnal penerimaan atas

penagihan piutang

Kas

$\operatorname{xxx}$

Usaha Piutang

$\mathrm{XXX}$

Pendapat lain menurut Martani dkk (2014:218-219), penurunan nilai akan dicatat mengurangi nilai piutang atau pinjaman. Ada dua metode untuk mencatat penurunan nilai yaitu metode penghapusan langsung (direct write off method) dan metode pencadangan (allowance method). Untuk metode penghapusan langsung, piutang yang diturunkan nilainya langsung dihapuskan tanpa dibuat akun cadangan penurunan nilai. Sedangkan metode pencadangan lebih tepat digunakan perusahaan dalam mencatat penurunan nilai. Pada saat perusahaan mengakui beban penurunan nilai piutang atau pinjaman, akan didebit akun cadangan penurunan nilai.

\section{F. Penyajian dan Pelaporan Piutang}

Untuk tujuan pelaporan, piutang dilaporkan sebesar nilai yang diharapkan dapat diterima dari piutang dagang yang bersangkutan. Konsep penilaian yang demikian menunjukkan bahwa aset lancar harus dinilai sebesar manfaat yang akan diterima di masa mendatang. Namun piutang harus tetap disajikan sebesar nilai transaksi yang sebenarnya (azaz bruto) kemudian disajikan cadangan kerugian piutang dan nilai bersih piutang bila perusahaan menggunakan metode cadangan. Dengan cara ini, pembaca dapat mengetahui jumlah bruto piutang usaha dan cadangan penghapusan piutang yang dibuat untuk piutang yang tidak dapat direalisasi.

Menurut Martani dkk (2014:226) menyatakan bahwa piutang dalam laporan posisi keuangan disajikan dalam kelompok aset lancar. Nilai piutang disajikan di laporan posisi keuangan setelah dikurangi dengan cadangan kerugian penurunan nilai. Piutang biasanya disajikan dalam satu baris, tetapi dapat juga disajikan secara detail subkomponennya. Jika disajikan dalam satu baris, maka subkomponennya disajikan dalam catatan atas laporan keuangan.

$$
\text { Menurut Mardiasmo (2016:63), }
$$
pelaporan piutang seharusnya dilakukan yaitu:

Penyajian piutang dagang di dalam laporan posisi keuangan dipisahkan dengan pos-pos piutang yang lain. Contoh penyajian pos piutang dagang dalam laporan posisi keuangan :

Piutang dagang (bruto)

\section{$\mathrm{Rp}$}

$\operatorname{xxx}$

Dikurangi: cadangan kerugian

$$
\begin{gathered}
\text { piutang } \\
\text { Piutang dagang (netto) } \\
\text { Rp xxx }
\end{gathered}
$$

Berdasarkan penjelasan di atas, diketahui bahwa nilai piutang yang disajikan di laporan posisi keuangan adalah sebesar nilai bersih piutang. Nilai bersih piutang yang didapat dihitung dengan cara mengurangi antara jumlah bruto piutang dengan cadangan kerugian piutang. Sehingga dalam hal penyajian di laporan posisi keuangan, piutang yang dilaporkan telah menunjukkan nilai sesungguhnya dari jumlah piutang bersih yang ada.

\section{METODE PENELITIAN}

\section{Jenis Penelitian}

Metode pendekatan penelitian yang penulis gunakan dalam penelitian ini adalah metode kualitatif, yaitu penelitian yang menguraikan sifat-sifat dan keadaan sebenarnya dari suatu objek penelitian. Pengertian metode kualitatif adalah metode yang digunakan untuk menggambarkan atau menganalisis suatu hasil penelitian tetapi tidak digunakan untuk membuat kesimpulan yang lebih luas.

\section{Teknik Pengumpulan Data}

Teknik pengumpulan data yang digunakan untuk analisa sistem pengendalian intern 
terhadap piutang pada PT.Divaindo Sentral Sarana adalah dengan melalui beberapa cara, antara lain :

1) Observasi

Teknik observasi peneliti melakukan pengamatan dan pencatatan langsung secara sistematis terhadap fenomena yang diselidiki. Dalam penelitian ini penulis mengumpulkan data dengan mengadakan pengamatan langsung terhadap piutang macet yang ada pada PT.Divaindo Sentral Sarana cabang Banjarbaru. Metode ini merupakan metode pengumpulan data, mencatat informasi yang disaksikan selama penelitian dan mencatat hal-hal yang diperlukan berkaitan dengan data yang diteliti.

2) Wawancara

Teknik melalui wawancara adalah teknik memperoleh informasi secara langsung melalui permintaan keterangan-keterangan kepada pihak pertama yang dipandang dapat memberikan keterangan dan jawaban terhadap pertanyaan yang diajukan yaitu dengan mengadakan pembicaraan langsung dengan karyawan yang bertugas dalam sistem pengendalian intern terhadap piutang pada PT.Divaindo Sentral Sarana. Wawancara ini dilakukan kepada bagian Akunting dan pimpinan PT.Divaindo Sentral Sarana.

3) Dokumentasi

Pengumpulan data melalui dokumentasi, diperlukan alat atau instrumen yang memandu untuk pengambilan data-data dokumen. Data dokumen dapat berupa foto, gambar, peta, grafik, struktur organisasi, catatan bersejarah, dan sebagainya. Metode dokumentasi ini digunakan untuk memperoleh data laporan keuangan piutang macet lembaga/organisasi yang terkait dengan sistem pengendalian intern piutang yang ada pada PT.Divaindo Sentral Sarana.

\section{Teknik Analisis Data}

Adapun metode kualitatif analisis data dengan pendekatan deskriptif terbagi menjadi 3 (tiga) yaitu :

1) Reduksi Data

Yakni merangkum, memilih hal-hal yang pokok. Memfokuskan pada hal-hal yang penting pada penelitian yang hanya masalah yang terkait pada Sistem Pengendalian Intern terhadap Piutang pada PT.Divaindo Sentral Sarana.

2) Penyajian Data

Adalah pengumpulan informasi yang terkait atas Sistem Pengendalian Intern terhadap Piutang pada PT.Divaindo Sentral Sarana yang kemudian nantinya akan memberikan kesimpulan atas penelitian yang diteliti tersebut.

3) Verifikasi/Kesimpulan

Verifikasi/kesimpulan adalah tahap terakhir dalam proses analisa data. Pada bagian ini penulis mengutarakan kesimpulan dari data-data yang diperoleh, atas judul penelitian yakni Sistem Pengendalian Intern terhadap Piutang pada PT.Divaindo Sentral Sarana.

\section{ANALISIS HASIL PENELITIAN DAN PEMBAHASAN}

\section{Gambaran Umum Objek Penelitian}

PT.Divaindo Sentral Sarana Cabang Banjarbaru merupakan salah satu perusahaan dagang yang bergerak dalam penjualan barang elektronik maupun furnitur baik secara tunai maupun kredit, namun aktivitas penjualannya didominasi oleh penjualan secara kredit. PT.Divaindo Sentral Sarana Cabang Banjarbaru berdiri pada 5 Mei 2012, yang merupakan anak perusahaan dari PT.Fidelindo Prosperous Utama (Columbus Group) yang bergerak dibidang yang sama, yaitu dalam penjualan barang elektronik dan furniture secara tunai maupun kredit.

PT.Divaindo Sentral Sarana Cabang Banjarbaru memiliki karyawan berjumlah 48 orang yang terdiri dari 1 Manager Operational Unit, 1 Head Accounting \& Finance, 1 administrasi marketing, 1 koordinator kredit, 2 administasi AR, 3 karyawan akunting, 6 tenaga penagih, 2 
analis, 4 bagian gudang 6 pramuniaga, dan 21 sales lapangan.

\section{Produk PT.Divaindo Sentral Sarana Cabang Banjarbaru}

Sesuai dengan permintaan konsumen kepada PT.Divaindo Sentral Sarana cabang Banjarbaru, dapat disiapkan produk sebagai berikut :

\section{Produk PT.Divaindo Sentral Sarana Cabang Banjarbaru}

\begin{tabular}{|c|l|}
\hline No & \multicolumn{1}{|c|}{ Nama Produk } \\
\hline 1 & $\begin{array}{l}\text { Barang Elektronik meliputi LED, } \\
\text { lemari es, mesin cuci, laptop, } \\
\text { komputer, printer, AC, kipas } \\
\text { angin, air cooler, handphone, } \\
2 \\
\text { music player, freezer, chest } \\
\text { freezer, penanak nasi, dll } \\
\text { Barang Furnitur meliputi lemari } \\
\text { pakaian, rak tv, sofa, kursi jati, } \\
\text { meja makan, meja kantor, lemari } \\
\text { hias, springbed, matras, dipan, } \\
\text { kitchen set, dll }\end{array}$ \\
\hline
\end{tabular}

Sumber : Data Diolah

\section{Data Penjualan Kredit}

Berikut data piutang PT.Divaindo Sentral Sarana cabang Banjarbaru

Tabel 4.3

Daftar Nilai Penjualan Kredit PT.Divaindo Sentral Sarana Tahun 2014-2018

\begin{tabular}{|c|c|c|c|c|}
\hline N & $\begin{array}{c}\text { TAH } \\
\text { UN }\end{array}$ & $\begin{array}{l}\text { JUMLAH } \\
\text { PIUTANG }\end{array}$ & $\begin{array}{c}\text { TUNGG } \\
\text { AKAN }\end{array}$ & $\%$ \\
\hline 1 & 2014 & $\begin{array}{r}10.229 .772 .00 \\
0\end{array}$ & $\begin{array}{r}484.775 .0 \\
00\end{array}$ & $\begin{array}{l}4,7 \\
4 \%\end{array}$ \\
\hline 2 & 2015 & 7.805 .737 .000 & $\begin{array}{r}366.132 .0 \\
00\end{array}$ & $\begin{array}{l}4,6 \\
9 \%\end{array}$ \\
\hline 3 & 2016 & 7.884 .617 .000 & $\begin{array}{r}368.791 .0 \\
00\end{array}$ & $\begin{array}{l}4,6 \\
8 \%\end{array}$ \\
\hline 4 & 2017 & 9.328 .584 .000 & $\begin{array}{r}421.860 .0 \\
00\end{array}$ & $\begin{array}{l}4,5 \\
2 \%\end{array}$ \\
\hline 5 & 2018 & 8.299 .093 .000 & $\begin{array}{r}480.310 .0 \\
00\end{array}$ & $\begin{array}{l}5,7 \\
9 \%\end{array}$ \\
\hline
\end{tabular}

Sumber Data : PT.Divaindo Sentral Sarana, 2019

Berdasarkan Tabel 1.1 di atas, dapat kita lihat perkembangan piutang dan besarnya tunggakan pada PT.Divaindo
Sentral Sarana, dimana pada tahun 2014 memiliki piutang sebesar Rp.10.229.772.000,- dan tunggakan Rp.484.775.000,- (4,74\%), pada tahun 2015 memiliki piutang sebesar Rp.7.805.737.000,- dan tunggakan Rp.366.132.000,- (4,69\%), pada tahun 2016 memiliki piutang sebesar Rp.7.884.617.000,- dan tunggakan Rp.368.791.000,- (4,68\%), pada tahun 2017 memiliki piutang sebesar Rp.9.328.584.000,- dan tunggakan Rp.421.860.000,- (4,52\%) terjadi kenaikan jumlah piutang pada tahun 2017 dibandingkan tahun-tahun sebelumnya begitu juga terjadi kenaikan nilai tunggakannya tetapi secara presentasi lebih rendah karena pembaginya yang besar, pada tahun 2018 memiliki piutang sebesar Rp.8.299.093.000,- dan tunggakan Rp.480.310.000,- (5,79\%).

Data Piutang Tak Tertagih

Daftar Piutang Tak Tertagih

PT.Divaindo Sentral Sarana

Tahun 2014-2018

\section{Sumber : Data Diolah}

Dari tabel di atas, dapat dilihat bahwa terjadi peningkatan jumlah piutang tak tertagih pada PT.Divaindo Sentral Sarana cabang Banjarbaru. Pada tahun 2014 nilainya cukup besar yaitu Rp.484.775.000,- pada tahun 2015 sebesar Rp.366.132.000,- pada tahun 2016 sebesar Rp.368.791.000,- pada tahun 2017 sebesar Rp.421.860.000,- pada tahun 2018 sebesar Rp.480.310.000,-

\section{PEMBAHASAN}

Sistem Pengendalian Intern Terhadap Piutang pada PT.Divaindo Sentral Sarana Cabang Banjarbaru yang selama ini dijalankan

\section{Komponen Sistem Pengendalian Intern terhadap Piutang}

1. Lingkungan Pengendalian

Lingkungan pengendalian merupakan salah satu komponen dari sistem pengendalian intern terhadap piutang 
yang meliputi perangkat standar, proses, dan struktur yang memberikan dasar pengendalian intern terhadap piutang tersebut. Pada dasarnya komponen manajemen pada PT.Divaindo Sentral Sarana cabang Banjarbaru sudah mempunyai kewenangan yang jelas. tetapi dalam pelaksanaannya tidak ada pemisahan tanggung jawab fungsional secara tegas.

2. Penilaian Risiko

Pada PT.Divaindo Sentral Sarana cabang Banjarbaru sudah memperhitungkan nilai risiko dalam setiap pelepasan kreditnya, dimana setiap pelepasan kredit telah dianalisa oleh bagian analis dengan metode 5C (Character, Capacity, Capital, Collateral, Condition). Dengan target minimal pencapaian 93,5\%. Prinsip 5C sesuai dengan Undang- undang Perbankan No 10 Tahun 1998 pasal 8.

3. Kegiatan Pengendalian

Pada komponen kegiatan pengendalian pada PT.Divaindo Sentral Sarana cabang Banjarbaru sudah berjalan dengan baik pada bagian penggunaan desain dokumen yang baik dan bernomor urut tercetak, namun masih sering terjadi pelanggaran dalam pemisahan tugas dan pemberian otorisasi terutama dalam proses penagihan.

4. Informasi dan Komunikasi

Informasi dan komunikasi tentang penanganan piutang pada PT.Divaindo Sentral Sarana cabang Banjarbaru sudah berjalan sangat baik, hal ini meliputi pengisian dan pencatatan semua transaksi yang valid, pencatatan transaksi pada periode yang tepat, dan penyajian transaksi dan pengungkapan terkait dalam laporan keuangan secara tepat.

5. Kegiatan Pemantauan

Kurangnya pengawasan dan pemantauan yang dilakukan oleh manajemen terutama dalam proses evaluasi berkelanjutan dan evaluasi terpisah yang meliputi sampling penagihan terhadap konsumen di lapangan.

\section{Unsur Sistem Pengendalian Intern terhadap Piutang}

1. Struktur organisai yang memisahkan tanggung jawab fungsional secara tegas Dalam struktur organisasi PT.Divaindo Sentral Sarana cabang Banjarbaru telah memisahkan tanggung jawab secara tegas, karena telah menunjukkan adanya pemisahan tugas dan tanggung jawab serta adanya pendelegasian wewenang. Dengan adanya fungsi ini membuat operasional perusahaan menjadi efisien dan ekonomis. Tetapi dalam pelaksanaannya terkadang banyak hal yang melewati batas tanggung jawabnya, misal saat tenaga marketing ikut melakukan proses penagihan yang bukan dari tanggung jawabnya.

\begin{tabular}{|c|c|c|}
\hline NO & TAHUN & TUNGGAKAN \\
\hline 1 & 2014 & 484.775 .000 \\
\hline 2 & 2015 & 366.132 .000 \\
\hline 3 & 2016 & 368.791 .000 \\
\hline 4 & 2017 & 421.860 .000 \\
\hline 5 & 2018 & 480.310 .000 \\
\hline
\end{tabular}

2. Sistem wewenang dan prosedur pencatatan yang memberikan perlindungan yang cukup terhadap kekayaan, utang, pendapatan, dan biaya Wewenang dan prosedur pencatatan yang memberikan cukup perlindungan terhadap kekayaan, utang, biaya, dan pendapatan merupakan bagian dari sistem pengendalian piutang, secara garis besar, siklus kegiatan perusahaan dagang meliputi kegiatan-kegiatan yaitu

1. Pembelian, dalam hal ini setiap pembelian harus melalui proses prosedur pencatatan, baik secara kontan maupun secara kredit.

2. Pengeluaran uang, yaitu pengeluaran uang harus dilakukan pencatatan dan atas persetujuan dari yang memiliki otorisasi sesuai dengan tugas dan tanggung jawab. 
3. Penjualan, yaitu penjualan barang baik secara kontan maupun secara kredit harus melalui pencatatan dan prosedur sesuai dengan wewenang masing-masing.

4. Penerimaan uang, seluruh penerimaan uang harus dicatat melalui prosedur sesuai dengan kewenangan masing-masing.

3. Praktek yang sehat dalam melaksanakan tugas dan fungsi setiap unit organisasi Praktek yang sehat dalam melaksanakan tugas dan fungsi setiap unit organisasi dengan cara adanya kerja sama antar bagian sudah dijalankan dengan sangat baik, tetapi dalam beberapa pelaksanaannya terutama pada bagian administrasi AR sering terjadi pelanggaran dimana mereka memberikan kewenangan terhadap karyawan lain seperti bagian marketing yang bukan bagian dari tenaga penagih untuk ikut membantu penagihan.

4. Karyawan yang memiliki mutu sesuai dengan tanggung jawabnya

Pada bagian tertentu terdapat karyawan yang tidak memiliki mutu yang sesuai dengan tanggung jawabnya, terutama pada bagian penagih yang berurusan langsung dengan konsumen dan menerima pembayaran piutangnya. Hal ini mengakibatkan banyaknya angsuran konsumen yang tidak disetor.

Begitu juga pada bagian administrasi AR yang seharusnya mengawasi dan memeriksa setiap pembayaran konsumen, mereka tidak melakukan kroscek di lapangan maupun melalui telepon atau pemeriksaan ulang kwitansi yang sudah diserahkan kepada bagian penagih, sehingga ketika tenaga penagih melakukan pelanggaran mereka tidak bisa mendeteksi secara cepat.

\section{Sistem Pengendalian Intern Terhadap Piutang yang Seharusnya pada PT.Divaindo Sentral Sarana Cabang Banjarbaru}

Komponen-komponen
Pengendalian Intern Piutang

\section{Lingkungan Pengendalian}

Lingkungan pengendalian perusahaan meliputi sikap para manajemen dan karyawan terhadap pentingnya pengendlian yang ada di organisasi tersebut. Salah satu faktor yang berpengaruh adalah filosofi manajemen dan gaya operasi manajemen, struktur organisasi serta praktek kepersonaliaan. Ligkungan pengendalian sangat penting karena menjadi dasar keefektifan unsur pengendalian intern yang lain, akan tertapi yang perlu mendapatkan perhatian dari PT.Divaindo Sentral Sarana cabang Banjarbaru dalam rangka perbaikan antara lain :

a. Integritas dan nilai-nilai etika, yaitu mutu atau sifat keadaan yang menujukkan satu kesatuan yang utuh yang memancarkan kewibawaan dari semua karyawan PT.Divaindo Sentral Sarana cabang Banjarbaru.

b. Kebijakan dan praktek pegawai, kebijakan yang ditetapkan dalam organisasi beserta prakteknya mempengaruhi perilaku kelompok maupun dalam tubuh organisasi.

\section{Penentuan Risiko}

Metode yang digunakan pada PT.Divaindo Sentral Sarana cabang Banjarbaru adalah menggunakan metode cadangan (Allowance Method) dimana perusahaan sudah memperhitungkan / estimasi risiko piutang yang tidak tertagih yaitu sebesar $5 \%$ dari total piutang serta setiap pelepasan kredit telah dianalisa oleh bagian analis dengan metode $5 \mathrm{C}$ (Character, Capacity, Capital, Collateral, Condition). Dengan target minimal pencapaian 93,5\%. Prinsip 5C sesuai dengan Undang- undang Perbankan No 10 Tahun 1998 pasal 8. Yang terdiri dari:

a. Charakter

Dalam hal ini perusahaan melihat kepribadian nasabah dengan melakukan beberapa tahapan seperti wawancara untuk mengetaui latar belakang, kebiasan hidup, pola hidup nasabah sehingga penilaian yang dilakukan kepada nasabah menghasilkan kerja sama yang baik antara nasabah, perusahaan dan bank. 
b. Capacity

Dalam hal ini perusahaan Bersama bank akan menilai kemampuan nasabah dalam menjalankan keuangan yang ada pada usahan yang dimilikinya, sehingga apakah nasabah pernah mengalami permasalahan keuangan atau tidak, segingga dapat melihat kemampuan nasabah didalam membayar kreditannya.

c. Capital

Dalam poin ini perusahaan menilai laporan yang dimiliki oleh nasabah dan jaminan yang juga disertakan sehingga apakah nasabah layak atau tidak untuk mendapat pinjaman lalu berapa besar bantuan kredti yang akan diberikan.

d. Collateral

Prinsip ini perlu diperhatikan bagi para nasabah Ketika mereka tidak dapat memenuhi kewajibannya dalam mengembalikan pinjaman, maka sesuai dengan ketentuan yang ada pihak perusahaan bisa saja menyita asset yang telah dijanjikan sebelumnya sebagai sebuah jaminan.

e. Condition

Prinsip ini di pengaruhi oleh factor diluar dari pihak perusahaan maupun nasabah, hal ini bis dilihat dari kondisi suatu daerah atau negara yang mempengaruhi dan hal ini harus menjadi perhatian dari kedua belah pihak untuk mencari solusi dan jalan keluar, apalagi masa- masa pandemi COVID 19 ini perlu adanya kebijakan seperti, potongan ansuran, kelonggran pembayaran dan lain sebagainya.

\section{Aktivitas Pengendalian}

Diperlukan adanya pengawasan dalam komponen aktivitas pengendalian ini, sekaligus evaluasi mengenai aktivitasaktivitas mengenai persetujuan dan kewenangan, terutama mengenai kebijakan kepala administrasi dan pimpinan secara struktural, sudah ada pemisahan tugas dan tanggung jawab.

\section{Informasi dan Komunikasi}

Dibutuhkan informasi yang update mengenai daftar semua piutang konsumen dan komunikasi antar karyawan yang baik agar dalam penanganan piutang bisa lebih maksimal lagi, dan disediakannya pembayaran konsumen secara online.

\section{Pengawasan dan Pemantauan}

Perlu adanya peningkatan dalam pemantauan yang dilakukan kepada karyawan terutama pada bagian yang berhubungan dengan penagihan piutang, karena pada bagian ini sering terjadi pelanggaran atas SOP dimana banyak aturan yang tidak dijalankan. Hal ini lah yang menimbulkan meningkatnya piutang tidak tertagih.

\section{Unsur-unsur Sistem Pengendalian Intern pada Piutang}

\section{Struktur Organisasi yang Memisahkan Tanggung Jawab Fungsional Secara Tegas}

Pada dasarnya struktur organisasi yang memisahkan tanggung jawab fungsional pada PT.Divaindo Sentral Sarana cabang Banjarbaru secara umum sudah baik, karena telah menunjukkan adanya pemisahan tugas. Struktur organisasi perusahaan disusun berbentuk garis lurus yang menyatakan adanya kesatuan perintah dan kepemimpinan.

1. Sistem Wewenang dan Prosedur Pencatatan yang Memberikan Cukup Perlindungan Terhadap Kekayaan, Utang, Biaya, dan Pendapatan

Sistem wewenang dan prosedur pencatatan yang memberikan cukup perlindungan terhadap kekayaan, utang, biaya dan pendapatan adalah unsur yang terdapat dalam sistem otorisasi dan prosedur pencatatan pelaksanaan baik penjualan kredit yang menimbulkan piutang harus sesuai dengan prosedur piutang dengan melaksanakan pencatatan umur piutang dan metode cadangan kerugian piutang.

2. Praktek yang Sehat dalam Melaksanakan Tugas dan Fungsi Setiap Unit Organisasi

Praktek sehat dalam melaksanakan tugas dan fungsi setiap unit organisasi adalah upaya menyelenggarakan fungsi organisasi berdasarkan kaidah-kaidah manajemen yang baik. Dalam 
pelaksanaannya seharusnya administrasi AR mencek ulang kwitansi yang sudah diserahkan kepada bagian penagihan untuk dilakukan pemeriksaan ulang setelah dilakukan penagihan, apakah konsumen tersebut bayar atau tidak.

\section{Karyawan Memiliki Mutu yang Sesuai dengan Tanggung Jawab}

Salah satu syarat agar sebuah perusahaan bisa sehat dan berkembang adalah karyawan yang memiliki mutu yang sesuai dengan tanggung jawab, memiliki kedisiplinan, kecakapan, dalam menjalankan tugasnya masing-masing. Selain itu kejujuran memberikan informasi dalam kinerja, dan perilaku yang bagus akan berdampak positif terhadap perusahaan.

\section{Flow chart Sistem Pengendalian Intern terhadap Piutang yang seharusnya}
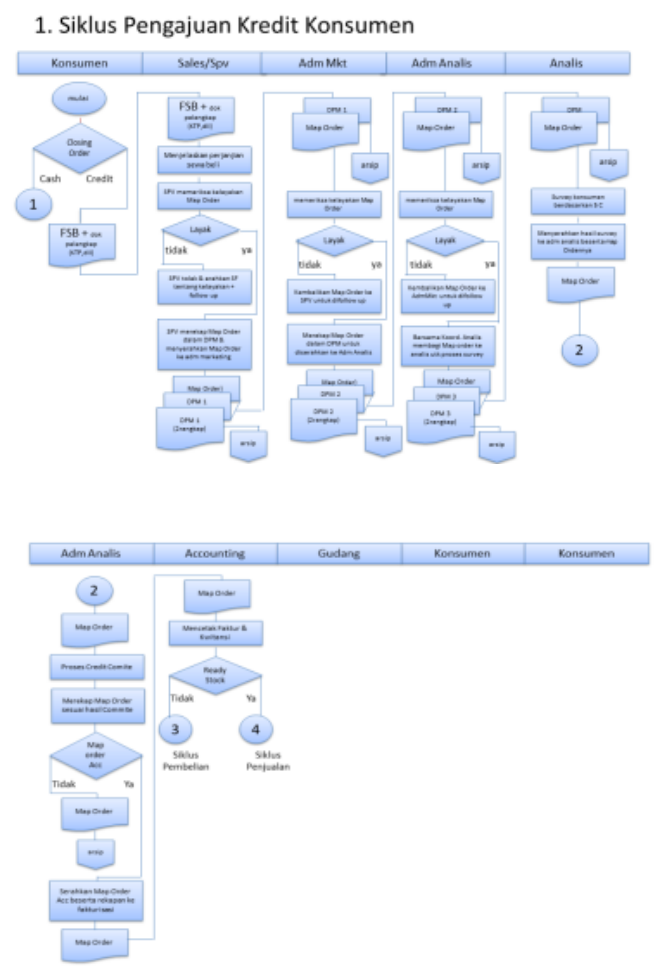

\section{KESIMPULAN \\ Pengendalian intern terhadap piutang yang selama ini Pada PT.Divaindo Sentral Sarana cabang Banjarbaru}

Pada dasarnya komponen manajemen pada PT.Divaindo Sentral Sarana cabang Banjarbaru sudah mempunyai kewenangan yang sangat jelas, tapi dalam pelaksanaannya tidak ada pemisahan tanggung jawab secara tegas

Dalam pelepasan kreditnya sudah menggunakan metode 5C (Character, Capacity, Capital, Collateral, Condition). Dengan target minimal pencapaian collection $93,5 \%$ dan tunggakan dibawah $5 \%$. (prinsip 5C pemeberian pembiayaan perbankan)

Kurangnya pengawasan dan pemantauan yang dilakukan oleh manajemen terutama dalam proses evaluasi berkelanjutan dan evaluasi terpisah yang meliputi sampling penagihan terhadap konsumen di lapangan.

Pengendalian intern terhadap piutang yang seharusnya Pada PT.Divaindo Sentral Sarana cabang Banjarbaru yang sesuai dengan Komponen dan Unsur Sistem Pengendalian Intern

Struktur Organisasi yang Memisahkan Tanggung Jawab Fungsional Secara Tegas, pada dasarnya secara umum sudah baik, karena telah menunjukkan adanya pemisahan tugas. Struktur organisasi perusahaan disusun berbentuk garis lurus yang menyatakan adanya kesatuan perintah dan kepemimpinan.

Praktek yang Sehat dalam Melaksanakan Tugas dan Fungsi Setiap Unit Organisasi, adalah upaya menyelenggarakan fungsi organisasi berdasarkan kaidah-kaidah manajemen yang baik. Dalam pelaksanaannya seharusnya administrasi AR mencek ulang kwitansi yang sudah diserahkan kepada bagian penagihan untuk dilakukan pemeriksaan ulang setelah dilakukan penagihan, apakah konsumen tersebut bayar atau tidak.

\section{SARAN}

Berdasarkan kesimpulan di atas, maka dalam penelitian ini penulis memberikan saran :

1. Sebaiknya perusahaan harus berani tegas dalam menjalankan SOP, sehingga tidak ada departemen lain dalam hal ini bagian marketing, yang tidak punya otoritas dalam proses penagihan ikut terlibat, sehingga tidak menimbulkan masalah yang mengakibatkan piutang tidak tertagih perusahaan tersebut meningkat. Serta 
harus lebih selektif lagi dalam memilih tenaga penagihan, harus bisa mendidik bagian penagih yang jujur, supel, dan dapat dipercaya.

2. Dalam menjalankan SOP, disarankan untuk dilakukan pemeriksaan ulang oleh bagian administrasi AR atas kwitansi yang sudah diberikan kepada bagian penagihan setiap hari, sehingga tidak ada kejadian pending setoran konsumen yang dilakukan oleh bagian penagihan.

3. Disediakannya pembayaran konsumen secara online, dimana hal ini dapat meminimalisir kecurangan yang dilakukan oleh karyawan.

4. Peningkatan batas target collection dari minimal 93,5\% menjadi 98\% sehingga hal ini bisa menurunkan piutang tak tertagih pad PT.Divaindo Sentral Sarana cabang Banjarbaru.

\section{DAFTAR PUSTAKA}

Carl S. Warren, dkk, 2014, Accounting Indonesia Adaptation, Salemba Empat, Jakarta.

COSO, 2013, Internal Control - Integrated Framework : Executive Summary, COSO, North Carolina.

Mardiasmo, 2016, Perpajakan Edisi Revisi Tahun 2016, Andi, Yogyakarta.

Martani, Dwi, dkk, 2014, Akuntansi Keuangan Menengah Berbasis PSAK, Salemba Empat, Jakarta.

Mulyadi, 2014, Sistem Akuntansi, Cetakan Keempat, Salemba Empat, Jakarta.

Purwaji, Agus, 2016, Akuntansi Biaya Edisi 2, Salemba Empat, Jakarta.

Romney, Marshall B, dan Steinbart, 2015, Sistem Informasi Akuntansi, Edisi 13 alih bahasa : Kikin Sakinah, Nur Safira, dan Novita Puspasari, Salemba Empat, Jakarta.

Sugiyono, 201, Metode Penelitian Kuantitatif, Kualitatif, Alfabeta, Bandung. 